\title{
KEEFEKTIFAN PENGGUNAAN MEDIA LAGU DALAM PEMBELAJARAN MENULIS PUISI SISWA KELAS VIII I SMPN 1 JEMBER
}

\author{
Rohmah Juwita Sari, Anjar Putro Utomo \\ Program Studi Pendidikan IPA, Fakultas Keguruan dan Ilmu Pendidikan Universitas Jember \\ email: juwitas071@gmail.com
}

\begin{abstract}
The purposes of this study were to describe the effectiveness of using song media in poetry writing skill for VIII I SMP N 1 Jember students. The data of this study were from the result of poetry writing skill pre-test and post-test by using song media in VIII I SMP N 1 Jember. Based on the result of data analysis and discussion, it can be concluded that (1) poetry writing skill of VIII I SMP N 1 Jember students without using song media with average 58,33, and (2) poetry writing skill VIII I SMP N 1 Jember students by using song media with average $72,26$.
\end{abstract}

Keywords: effectiveness, song media, writing poetry

\section{PENDAhUluan}

Puisi merupakan suatu karya sastra yang bernilai tinggi, terutama yang tertuang dalam bentuk atau tipografi yang berbeda dari karya sastra lainnya. Dalam penulisan puisi terkadang penulis menciptakannya dengan tipografi yang berbeda-beda, dengan tujuan tulisan itu menjadi lebih indah dan baik saat dipandang, dibaca, ataupun diperdengarkan.

Mulyana (dalam Semi, 1988:83) menyatakan bahwa puisi adalah sintesis dari berbagai peristiwa bahasa yang telah tersaring semurni-murninya dan sebagai proses jiwa yang mencari hakikat pengalamannya, tersusun dengan sistem pengulangan-pengulangan korespondensi dalam satu bentuk. Mulyana (dalam Waluyo, 1987:23) menyatakan bahwa puisi merupakan kesusastraan yang menggunakan pengulangan suara sebagai ciri khasnya. Pengulangan kata itu akan menghasilkan rima, ritma, dan musikalitas. Jika pengertian puisi ditinjau dari segi bentuk batin puisi, Herbert (dalam Waluyo, 1987:23) menyatakan bahwa puisi merupakan bentuk pengucapan yang bersifat emosional dengan mempertimbangkan efek keindahan.

Untuk memahami puisi, perlu diketahui ciri-ciri yang terkandung di dalamnya. Atmazaki (1993:8-13) mengemukakan lima ciri puisi. Ciri tersebut adalah sebagai berikut. Pertama, puisi memiliki unsur formal, yaitu bahasa yang tersusun dalam baris dan bait serta unsur nonformal, yaitu irama. Ada puisi yang tidak memperhatikan unsur bahasa, untuk puisi seperti itu ditentukan oleh irama yang terkandung di dalamnya. Kedua, puisi tidak bercerita. Berbeda dengan karya sastra yang berbentuk prosa, puisi tidak merupakan suatu deretan peristiwa dan juga tidak memiliki alur. Puisi adalah monolog, monolog seorang subjek lirik. Sebagai monolog, kekuatan puisi terletak pada kekuatan ekspresinya. Daya ekspresi puisi tidak tergantung pada jumlah kata yang digunakan, tetapi pada pemanipulasian dan pemilihan kata yang mampu mengkonkritkan imaji-imaji yang memenuhi intuisi penyair. Ketiga, unsur dasar puisi adalah baris dan lirik. Keterikatan sebuah kata dalam puisi lebih cenderung kepada struktur ritmik sebuah baris daripada struktur sintaksis sebuah kalimat seperti prosa. Oleh sebab itu, unsur dasar puisi bukanlah kalimat, melainkan baris dan irama yang muncul manakala puisi dibacakan. Walaupun kata-kata terikat pada baris, namun tidak berarti bahwa kata dalam puisi tidak dapat dikembalikan pada struktur kalimat. Hanya saja peranan baris lebih menentukan dibandingkan kalimat. Keempat, bahasa puisi cenderung bermakna konotatif. Hal yang sangat dominan ditemukan dalam puisi. Hampir tidak ada puisi yang dimanfaatkan konotasi bahasa, karena itulah alamiah puisi. Ketidaklangsungan ucapan adalah darah

\section{ScienceEdu Vol. II. No. 2 Desember 2019}


daging sebuah puisi. Kelima, pembaca membaca sebuah puisi sebagai sebuah puisi. Bila membaca mempersiapkan dirinya secara mental berhadapan dengan teks puisi maka pembaca akan memperoleh apresiasi tentang sebuah puisi. Artinya, peranan pembaca sangat menentukan tentang keberadaan sebuah karya sastra.

Berdasarkan observasi dengan guru bidang studi, pembelajaran puisi siswa kelas VIII I SMP N 1 Jember kurang mampu menggunakan indikator diksi, citraan, dan majas. Karena diksi, citraan, dan majas merupakan hal yang penting dinilai dalam pembelajaran menulis puisi.

Diksi dalam arti aslinya, merujuk pada pemilihan kata dan gaya ekspresi oleh penulis atau pembicara. Menurut Semi (1984:110) menyatakan kata merupakan persoalan pokok puisi, merupakan bahan baku puisi. Selanjutnya, Pradopo (1990:54) mengatakan bahwa dengan puisi penyair dapat mencurahkan perasaan dan isi pikiran dengan setepat-tepatnya yang dialami oleh batinnya saat itu. Pilihan kata itulah yang disebut dengan diksi. Hasanuddin (1989:44) mengemukakan dalam perpuisian Indonesia ditemukan lima aneka ragam kosa kata oleh penyair yaitu, (1) kosa kata sehari-hari, (2) kosa kata purba, (3) kosa kata daerah, (4) kosa kata asing, dan (5) kosa kata vulgar. Kosa kata sehari-hari digunakan untuk menampilkan kesan yang lebih realistis lantaran yang digambarkannya persoalan rutinitas. Kosa kata purba atau atavis adalah kosa kata lama yang sudah tidak digunakan lagi untuk berkomunikasi sehari-hari. Kosa kata daerah adalah kosa kata yang digunakan penyair untuk menimbulkan kesan yang tepat bagi suatu konsep yang dikenalnya kerana bahasa yang dikenalnya adalah bahasa daerahnya. Kosa kata asing digunakan penyair untuk mengungkapkan konsep yang tidak mungkin diterjemahkan ke dalam bahasa Indonesia. Kosa kata vulgar adalah kosa kata yang kasar, kurang sopan, dan seenaknya.

Semi (1988: 124) mengatakan bahwa citraan merupakan salah satu unsur puisi yang berkaitan dengan pemanfaatan bahasa dalam mendukung pengertian tertentu. Pada dasarnya persoalan ini berkaitan dengan diksi, yaitu penataan kata yang menyebabkan makna-makna abstrak menjadi konkret dan cermat. Hasanuddin (2002:117-129) mengatakan citraan dibagi atas enam, yaitu citraan penglihatan, pendengaran, penciuman, rasaan, rabaan, dan gerakan. Pertama, citraan penglihatan adalah citraan yang timbul karena daya saran penglihatan. Citraanpenglihatan memberikan rangsangan pada indera penglihatan, hingga sering hal-hal yang tidak terlihat jadi seolah-olah terlihat. Kedua, citraan pendengaran merupakan segala sesuatu yang berhubungan dengan usaha memancing bayangan pendengar guna membangkitkan suasana tertentu dalam puisi. Penyajian puisi dengan menggunakan citraan pendengaran seolaholah mengajak pembaca ikut mendengar apa yang dirasakan oleh penyair. Ketiga, citraan penciuman adalah ide-ide abstrak yang dikonkretkan oleh penyair dengan cara melukiskan atau menggambarkan lewat rangsangan yang seolah-olah dapat ditangkap oleh indera penciuman. Keempat, citraan rasaan, yaitu penyair menggambarkan sesuatu dengan mengetengahkan ataumeilih kata-kata untuk membangkitkan emosi pada puisi untuk mengiring daya bayang pembaca lewat sesuatu yang seolah-olah dapat dirasakan oleh indera pencecapan pembaca. Kelima, citraan rabaan merupakan citraan yang mampu menciptakan suatu daya saran bahwa seolah-olah pembaca dapat tersentuh, bersentuhan, atau apapun yang dapat melibatkan efektivitas indera kulitnya. Keenam, citraan gerak dimanfaatkan dengan tujuan lebih menghidupkan gambaran dengan melukiskan sesuatu objek yang digambarkan seolah-olah bergerak, meskipun terkadang gerakan itu tidak dapat diterima oleh akal sehat. Majas merupakan keindahan dan kreaatifitas penyair dalam menggunakan bahasa. Majas sering disebut dengan gaya bahasa, padahal pada hakikatnya majas dan gaya bahasa itu berbeda. Beberapa ahli bahasa memaparkan tentang majas dalam puisi.

Menurut Waluyo (1987:83), majas atau gaya bahasa merupakan bahasa 
figuratif. Bahasa figuratif menyebabkan puisi menjadi prismatis, artinya memancarkan banyak makna atau kaya akan makna. Bahasa figuratif adalah bahasa yang digunakan penyair untuk mengatakan sesuatu dengan cara yang tidak biasa, secara tidak langsung mengungkapkan makna. Majas dibagi atas enam. Pertama, metafora adalah kiasan langsung artinya benda yang dikiaskan itu tidak disebutkan. Jadi, ungkapan itu langsung berupa kiasan. Metafora sebagai perbandingan langsung tidak mempergunakan kata seperti, hal, bagaikan, dan sebagainya, sehingga pokokpokok pertama langsung dihubungkan dengan pokok kedua. Contohnya, raja hutan melambangkan orang yang paling kuat dan paling ditakuti oleh semua orang, hidung belang melambangkan seseorang yang ganti-ganti pasangan (cowok).

Kedua, perbandingan adalah kiasan yang langsung disebutkan perbandingannya atau simile.Benda yang dimiaskan keduaduanya ada bersama pengiasnya dan digunakan kata-kata seperti, laksana, bagaikan, bagai, bak, dan sebagainya. Contohnya, pendapatnya seperti air di atas daun talas.

Ketiga, personifikasi adalah keadaan atau peristiwa yang dialami manusia. Padapersonifikasi benda mati dianggap sebagai manusia atau persona, atau dipersonifikasikan. Hal ini digunakan untuk memperjelas penggambaran peristiwa keadaan itu. Contohnya, pena menari-nari di atas kertas.

Keempat, hiperbola adalah kiasan yang mengandung suatu pernyataan yang berlebihandengan membesar-besarkan suatu hal. Penyair merasa perlu melebih-lebihkan hal yang dibandingkan agar mendapatkan perhatian yang lebih seksana dari pembaca. Contohnya, suaranya menggelegar membelah langit.

Kelima, sinekdoke adalah semacam bahasa figuratif yang mempergunakan sebagian darisuatu hal untuk menyatakan keseluruhan (pars pro toto) atau mempergunakan keseluruhan untuk menyatakan sebagian (totum pra parte). Contohnya, Indonesia memenangkan pertandingan bulu tangkis (pars pro toto) dan setiap kepala harus membayar pajak (totem pro parte).

Keenam, ironi adalah gaya bahasa yang berupa penyampaian maksud penutur kepada mitratuturnya secara tidak langsung. Contohnya, rapi sekali kamarmu seperi kapal pecah.

Berdasarkan hasil pengamatan di atas, salah satu permasalahan yang dihadapi siswa dalam pembelajaran keterampilan menulis puisi adalah tidak menariknya media pembelajaran. Kekurangmenarikan media tersebut dapat menyebabkan ketidaktercapaian tujuan pembelajaran yang hendak dicapai. Untuk mengatasi permasalahan tersebut, siswa kelas VIII I SMP N 1 Jember diberikan suatu perlakuan yaitu penggunaan media lagu dalam pembelajaran keterampilan menulis puisi.

Suharto (dalam Wardah, 2005:37) mengungkapkan bahwa lagu adalah sarana informasi dan edukasi bagi negara dan bagi masyarakat. Sebagai sarana informasi, lagu sebagai sarana penyampaian ungkapan hati atau ungkapan perasaan seorang penyair kepada pendengar. Sebagai sarana edukasi lagu dapat digunakan sebagai media dalam pembelajaran di sekolah karena lagu merupakan salah satu bentuk karya seni. Lagu merupakan karya yang estetis yang bermakna dan mempunyai arti bukan hanya sesuatu yang kosong tanpa makna. Oleh karena itu sebelum mengkaji aspek-aspek yang lain perlu lebih dahulu dikaji lagu sebagai sebuah struktur yang bermakna dan bernilai estetis. Penciptaan lagu dapat memberikan kesenangan juga berharap bagi para penikmat dapat mengerti maksud yang terkandung dalam lagu tersebut yang merupakan jalinan komunikasi.

Gustiani (2006:30) mendefinisikan lagu sebagai ragam sastra yang berirama dalam bercakap, bernyanyi, membaca, dan sebagainya. Lagu termasuk ke dalam media audio karena lagu merupakan hal atau sesuatu yang berkaitan dengan indera pendengaran. Secara fisiologis, pendengaran adalah suatu proses gelombang-gelombang suara masuk melalui telinga bagian

luar, terus ke gendang telinga, kemudian dirubah menjadi getaran mekanik 
di bagian tengah telinga, selanjutnya berubah menjadi rangsangan syaraf, dan diteruskan ke otak. Lagu adalah ragam suara yang berirama (dalam bercakap, bernyanyi, membaca, dan sebagainya); nyanyian; ragam bunyi; dan tingkah laku (KBBI: 2008:771).

Media lagu merupakan sebuah alat yang menggunakan Flash disk yang hanya menghasilkan audio tanpa gambar. Flash disk ini harus diputar dengan menggunakan Laptop atau komputer.

Gustiani (2006: 32) Kelebihan dari media ini adalah pertama bisa diputar berulang-ulang sesuai kebutuhan siswa, kedua lagu dapat dihapus dan digunakan kembali, ketiga mampu mengembangkan imajinasi siswa, keempat sangat efektif untuk pembelajaran bahasa, kelima penggandaan programnya sangat mudah sehingga bisa diberikan kepada setiap anak didik. Adapun kelemahan dari media ini yaitu pertama biaya pembelian alatnya relatif lebih mahal. Oleh karena itu, jika ada anak didik yang membutuhkannya, maka harus mengeluarkan biaya untuk membeli flash disk tersebut.

Dalam penelitian ini, media audio lagu digunakan sebagai media pembelajaran. Artinya, dalam proses pembelajaran, media lagu berupa lirik lagu yang diperdengarkan kepada siswa digunakan sebagai alat bantu pembelajaran dalam menulis puisi. Tujuan penelitian ini adalah untuk melihat ada atau tidaknya keefektifan media audio lagu tersebut terhadap keterampilan menulis puisi siswa kelas VIII I SMP N 1 Jember.

\section{METODE PENELITIAN}

Jenis penelitian ini adalah penelitian kuantitatif dengan menggunakan metode eksperimen. Dikatakan penelitian kuantitatif karena hasil pengukuran banyak dituntut menggunakan angka, mulai dari proses pengumpulan data, penafsiran terhadap data, serta penampilan dari hasilnya (Arikunto, 2002:10). Selanjutnya, metode eksperimen digunakan karena penelitian ini bertujuan untuk mengontrol atau mengendalikan setiap gejala yang muncul dalam kondisi tertentu, sehingga dapat diketahui hubungan sebab-akibat dari gejala yang terjadi.

Penelitian ini dilakukan untuk mengetahui ada atau tidaknya keefektifan media audio lagu terhadap keterampilan menulis puisi siswa kelas VIII I SMP N 1 Jember. Indikator penilaian yang digunakan terdiri atas tiga, yaitu citraan, diksi, dan majas. Dengan kata lain, hasil tes siswa dinilai berdasarkan ketiga indikator tersebut.

Sampel penelitian ini terdiri atas satu kelompok, yaitu kelompok eksperimen. Sampel yang diambil adalah kelas VIII I dengan jumlah siswa 30 orang, namun ketika penelitian siswa yang datang hanya 22 orang. Jadi, penilaian dilakukan hanya kepada 22 orang siswa.

Data utama dalam penelitian ini adalah hasil tes keterampilan menulis puisi dengan menggunakan media lagu. Data tersebut diperoleh dari tes akhir yang diberikan pada sampel. Data yang diperoleh selanjutnya dianalisis melalui langkahlangkah berikut. Pertama, memberikan skor berdasarkan indikator. Kedua, mengubah skor menjadi nilai. Ketiga, mengklasifikasikan keterampilan menulis cerpen siswa berdasarkan pedoman konversi skala. Keempat, menentukan ratarata hitung siswa dan menafsirkannya dengan KKM. Kelima,membandingkan keterampilan menulis cerpen kelompok eksperimen dan kelompok kontrol dengan menggunakan rumus uji-t untuk melihat pengaruh yang terjadi. Keenam, menyimpulkan hasil penelitian dan pembahasan.

\section{HASIL DAN PEMBAHASAN}

Berdasarkan hasil analisis data, diketahui bahwa keterampilan menulis puisi siswa kelas VIII I SMP N 1 Jember tanpa menggunakan media lagu dikelompokkan menjadi enam kualifikasi. Pertama, baik (B) terdiri atas 1 orang $(4,55 \%)$, yaitu siswa yang tingkat penguasaannya antara 76-85. Kedua, lebih dari cukup (LdC) terdiri atas 1 orang $(4,55 \%)$, yaitu siswa yang tingkat penguasaanya antara 66-75. Ketiga, lebih dari cukup $(\mathrm{LdC})$ terdiri atas 10 orang 
$(45,45 \%)$, yaitu siswa yang tingkat penguasaanya antara 66-75. Keempat, cukup (C) terdiri atas 4 orang $(18,18 \%)$, yaitu siswa yang tingkat penguasaanya antara 56-65. Kelima, hampir cukup (HC) terdiri atas 3 orang $(13,63 \%)$, yaitu siswa yang tingkat penguasaannya antara 46-55. Keenam, kurang sekali (KS) terdiri atas 3 orang $(13,63 \%)$, yaitu siswa yang tingkat penguasaanya antara 26-35.

Nilai rata-rata keterampilan menulis puisi siswa kelas VIII I SMP N 1 Jember tanpa menggunakan media lagu adalah 58,33 berada pada kualifikasi cukup (C). Jika dibandingkan dengan kriteria ketuntasan minimal (KKM) mata pelajaran bahasa Indonesia di VIII I SMP $\mathrm{N} 1$ Jember, yaitu 70, disimpulkan bahwa keterampilan menulis puisi siswa kelas VIII I SMP N 1 Jember tanpa menggunakan media lagu belum memenuhi KKM. Berikut ini dibahas keterampilan menulis puisi siswa per indikator.

Ditinjau dari masing-masing indikator, keterampilan menulis puisi siswa kelas VIII I SMP N 1 Jember tanpa menggunakan media lagu adalah sebagai berikut. Pertama, untuk indikator I (diksi), keterampilan menulis puisi siswa berada pada kualifikasi hampir cukup (HC) dengan rata-rata hitung 53,02. Kedua, untuk indikator II (citraan), keterampilan menulis puisi siswa berada pada kualifikasi Baik (B) dengan rata-rata hitung 84,85. Ketiga, untuk indikator III (majas), keterampilan menulis puisi siswa berada pada kualifikasi Lebih dari Kurang (K) dengan rata-rata hitung 34,85. Berdasarkan hasil tersebut, disimpulkan bahwa keterampilan menulis puisi siswa kelas VIII I SMP N 1 Jember dengan menggunakan media lagu tertinggi berada pada indikator II (citraan) dan terendah berada pada indikator III(majas).

Keterampilan Menulis Puisi Siswa dengan Menggunakan Media Lagu Siswa Kelas VIII I SMPN 1 Jember

Berdasarkan hasil analisis data, disimpulkan bahwa tingkat keterampilan menulis puisi siswa kelas VIII I SMP N 1 Jember dengan menggunakan media lagu terdiri atas enam kualifikasi. Pertama, sempurna $(\mathrm{S})$ terdiri atas 1 orang $(4,54 \%)$, yaitu siswa yang tingkat penguasaanya berkisar 96-100. Kedua, baik (B) terdiri atas 7 orang $(31,82 \%)$, yaitu siswa yang tingkat penguasaanya berkisar 76-85. Ketiga, lebih dari cukup (LDC) terdiri atas 5 orang $(22,73)$, yaitu siswa yang tingkat penguasaanya berkisar 66-75. Keempat, lebih dari cukup (LDC) terdiri atas 6 orang $(27,27 \%)$, yaitu siswa yang tingkat penguasaanya berkisar 66-75). Kelima, cukup (C) terdiri atas 2 orang $(9,09)$, yaitu siswa yang tingkat penguasaanya berkisar 56-65. Keenam, hampir cukup (HC) terdiri atas 1 orang siswa $(4,54)$, yaitu siswa yang tingkat penguasaannya berkisar 46-55.

Nilai rata-rata keterampilan menulis puisi siswa kelas VIII I SMP N 1 Jember dengan menggunakan media lagu adalah 72,26 dan berada pada kualifikasi lebih dari cukup (LdC). Jika dibandingkan dengan KKM mata pelajaran bahasa Indonesia di VIII I SMP N 1 Jember yaitu 70, disimpulkan bahwa keterampilan menulis puisi siswa kelas VIII I SMP N 1 Jember dengan menggunakan media lagu sudah memenuhi KKM. Ditinjau dari masingmasing indikator, keterampilan menulis puisi siswa kelas VIII I SMP N 1 Jember dengan menggunakan media lagu adalah sebagai berikut. Pertama, untuk indikator I (diksi), keterampilan menulis puisi siswa berada pada kualifikasi Lebih dari Cukup (LdC) dengan rata-rata hitung 68,18. Kedua, untuk indikator II (citraan), keterampilan menulis puisi siswa berada pada kualifikasi Baik Sekali (BS) dengan rata-rata hitung 89,39. Ketiga, untuk. cerpen siswa berada pada kualifikasi Cukup (C) dengan rata-rata hitung indikator III (majas), keterampilan menulis 63,64.

Berdasarkan hasil tersebut, disimpulkan bahwa keterampilan menulis puisi siswa kelas VIII I SMP N 1 Jember dengan menggunakan media lagu tertinggi berada pada indikator II (citraan) dan terendah berada pada indikator III (majas).

Perbandingan Penggunaan Media Lagu Tanpa Menggunakan Media Lagu dan dengan Menggunakan Media Lagu terhadap Keterampilan Menulis Puisi Siswa Kelas VIII I SMPN 1 Jember 
Hipotesis penelitian dilakukan untuk mengetahui ada atau tidaknya keefektifan media lagu terhadap keterampilan menulis puisi siswa kelas VIII I SMP N 1 Jember. Hal tersebut diketahui dengan cara membandingkan keterampilan menulis puisi siswa kelas VIII I SMP N 1 Jember tanpa menggunakan media lagu dan menggunakan media lagu. Sebelum dilakukan uji-t, terlebih dahulu diuji normalitas dan homogenitas kelompok data.

Uji normalitas data dilakukan untuk mengetahui apakah data berdistribusi normal atau tidak. Uji normalitas dilakukan dengan uji Liliefors. Berdasarkan uji Liliefors, disimpulkan bahwa data sampel berdistribusi normal pada taraf signifikansi 0,05 untuk untuk $n=22$ karena L0 kecil dari Ltabel $(0,1508$ kecil dari 0,190). Uji homogenitas data dilakukan untuk mengetahui apakah kelompok data memiliki homogenitas atau tidak. Uji homogenitas dilakukan dengan menggunakan rumus perbandingan varian terbesar dengan varian terkecil. Berdasarkan uji homogenitas yang dilakukan, disimpulkan bahwa kelompok data homogen pada taraf signifikansi 0,05 untuk $n=22$ karena Fhitung kecil dari Ftabel (1,36 kecil dari 2,09).

Selanjutnya dilakukan uji hipotesis dengan menggunakan rumus uji-t. Berdasarkan hasil uji-t, disimpulkan bahwa hipotesis alternatif (H1) diterima pada taraf signifikansi $95 \%$ dan $\mathrm{dk}=\mathrm{n} 1+\mathrm{n} 2-2$ karena thitung $>$ ttabel $(2,23>1,67)$.

Berdasarkan hasil pengamatan saat proses pembelajaran, penggunaan media lagu sangat menarik bagi siswa. Hal tersebut terbukti dengan antusiasme siswa untuk mengikuti pembelajaran. Setelah pemutaran lagu dilakukan, siswa dapat mengembangkan imajinasinya dalam bentuk tulisan. Hal tersebut sejalan dengan pendapat Gustiani (2006: 32) yang menyatakan bahwa salah satu keuntungan media lagu adalah mengembangkan imajinasi siswa. Selain itu, pemutaran lagu membuat siswa sangat efektif dalam pembelajaran. Ditinjau dari hasil tes keterampilan menulis puisi yang diberikan kepada siswa, hasil tes dengan menggunakan media lagu lebih tinggi dibandingkan dengan tanpa menggunakan media lagu.

Berdasarkan hasil analisis diperoleh gambaran tentang keterampilan menulis puisi tanpa menggunakan media lagu dan keterampilan menulis puisi menggunakan media lagu siswa kelas VIII I SMP N 1 Jember ada temuan positif dan negatif. Temuan positif yaitu, (1) siswa sudah mampu menulis puisi dengan menggunakan media lagu yang didengar dari penggunaan citraan dan majas, (2) siswa lebih tertarik menulis puisi dengan menggunakan media lagu daripada tanpa menggunakan media lagu. Hal ini dibuktikan dengan nilai ratarata yang diperoleh siswa menulis puisi dengan menggunakan media lagu lebih tinggi daripada tanpa menggunakan media lagu.

Temuan negatif yaitu, keterampilan menulis puisi dengan menggunakan media lagu siswa kelas VIII I SMP N 1 Jember dilihat dari kualifikasi tingkat penguasaan masing-masing indikator belum semuanya mampu mencapai tingkat sempurna. Bahkan masih terdapat keterampilan puisi yang berkualifikasi kurang sekali. Faktor yang menyebabkan hal ini terjadi adalah siswa kurang memahami majas. Berdasarkan temuan tersebut apabila dilihat dari rata-rata nilai, nilai tertinggi dari dua indikator kemampuan menulis puisi dengan menggunakan media lagu dan tanpa menggunakan media lagu adalah indikator citraan. Nilai yang terendah dari dua indikator keterampilan menulis puisi dengan menggunakan media lagu dan tanpa menggunakan media lagu adalah indikator majas.

Dari uraian tersebut dapat diambil kesimpulan, bahwa guru merupakan orang yang terlibat dalam meningkatkan keterampilan menulis puisi siswa. Oleh karena itu, guru perlu merencanakan, melaksanakan, mengevaluasi dan menvariasikan pembelajaran agar tidak monoton. Hal itu dapat dilakukan dengan memberikan latihan menulis puisi dengan pembelajaran yang menarik.

\section{SIMPULAN}


Berdasarkan temuan penelitian dan pembahasan, keterampilan siswa menulis puisi tanpa menggunakan media lagu dan menggunakan media lagu kelas VIII I SMP $\mathrm{N} 1$ Jember, diperoleh tiga kesimpulan sebagai berikut. Pertama, sempurna (S) terdiri atas 1 orang $(4,54 \%)$, yaitu siswa yang tingkat penguasaanya berkisar 96-100. Kedua, baik (B) terdiri atas 7 orang $(31,82 \%)$, yaitu siswa yang tingkat penguasaanya berkisar 76-85. Ketiga, lebih dari cukup (LDC) terdiri atas 5 orang $(22,73)$, yaitu siswa yang tingkat penguasaanya berkisar 66-75. Keempat, lebih dari cukup ( $\mathrm{LdC})$ terdiri atas 6 orang $(27,27 \%)$, yaitu siswa yang tingkat penguasaanya berkisar 66-75). Kelima, cukup (C) terdiri atas 2 orang $(9,09)$, yaitu siswa yang tingkat penguasaanya berkisar 56-65. Keenam, hampir cukup (HC) terdiri atas 1 orang siswa $(4,54)$, yaitu siswa yang tingkat penguasaannya berkisar 46-55. Terdapat perbedaan yang signifikan antara pretest dan posttest keterampilan menulis puisi dengan menggunakan media lagu siswa kelas VIII I SMP N 1 Jember. Dengan kata lain, keterampilan menulis puisi siswa kelas VIII I SMP N 1 Jember nilai posttest lebih tinggi dibandingkan dengan nilai pretest.

\section{SARAN}

Sebaiknya sebelum melakukan penelitian maupun observasi penulis lebih memahami apa yang akan dilakukan ditempat observasinya agar tidak memperlambat waktu pengerjaan serta menyiapkan data data yang akan diperlukan di tempat observasi terlebih dahulu agar tidak bingung dan tergesa gesa.

\section{UCAPAN TERIMA KASIH}

Penulis ingin mengucapkan banyak banyak puji Syukur kepada Allah S.W.T yang meridhoi penelitian serta observasi di SMPN 1 Mayang hingga selesai dengan keadaan yang sehat wal afiat. Serta titak lupa pula untuk memanjatkan Sholawat serta salam kepada junjungan kami nabi besar Muhammad S.A.W. Sebelumnya saya ingin berterima kasih banyak untuk kakak saya yang mau membantu dalam pengerjaan artikel ini terutama menentukan tema artikel ini dikarenakan kakak saya yang jurusan pendidikan sastra. Tak lupa pula saya ingin mengucapkan terima kasih banyak untuk pihak SMPN 1 Jember yang mau menerima saya. Serta saya ingin mengucapkan banyak banyak terima kasih kepada bapak ibu guru yang telah mau membantu saya dalam penelitian ini serta membantu dalam mengumpulkan data data yang saya inginkan. Serta saya ucapkan banyak banyak terima kasih untuk orang tua saya yang mendoakan saya serta terus memberikan saya semangat serta membantu saya baik bathil maupun bathin.

\section{DAFTAR PUSTAKA}

Arikunto, Suharsimi. 2002. Prosedur Penulisan. Jakarta: Rineka Cipta.

Atmazaki. 1993. Analisis Sajak: Teori Metodologi dan Aplikasi. Bandung: Angkasa.

Depdikbud. 2008. Kamus Besar Bahasa Indonesia. Jakarta: Gramedia Pustaka Utama

Hasanuddin, WS. 2002. Membaca dan Menilai Sajak. Bandung: Angkasa.

Pradopo, Rachmat Djoko. 1987. Pengkajian Puisi. Yogyakarta: Gadja Mada University Press

Semi, Atar. 1988. Anatomi Sastra. Padang: Sridharma.

Waluyo, Herman. J. 1987. Teori dan Apresiasi Puisi. Jakarta: Erlangga. 